\title{
Food Processing Value Chains in Zambia: Governance in the Maize Value Chain
}

\author{
Matildah Kaliba \\ Zambia \\ *Corresponding Author: Matildah Kaliba, Zambia

\begin{abstract}
Governance has been one of the key analytical dimensions within global value chains. In this paper, the global value chain framework is applied to analyse the governance structure in the Zambian Maize value chain. The paper aims to understand how the maize value chain is organised, its forms of coordination and the overall implication of the governance structure on local processing firms. It uses both primary and secondary data sources. The primary data was collected from interviews with a number of value chain actors including farmers, grain traders, processing firms, retailers and key stakeholder. The findings indicate that the Zambian maize value chain has shifting patterns of coordination. Further, different types of governance structures exist at different nodes of the chain. Because maize meal which is the key commodity produced in the value chain is Zambia's staple food, government intervenes through various ministries at their control and directly through political pronouncements thereby changing the coordination mechanisms that may be at play at a given time. The study concludes that the configuration of the maize value chain can neither be said to buyer driven nor producer driven contrary to the postulation by early GVC scholars.
\end{abstract}

Keywords: Global value chains, Maize, Staple food, Governance, Zambia, Local Value chain

\section{INTRODUCTION}

The analytical dimension of governance within global value chains has attracted a number of scholars over the years (Gereffi, 1994; Gibbon and Ponte, 2005; Granleese, 2009; Ponte, 2014). However, for Africa, these studies have been limited to high value crops such as cocoa, coffee, fruits and vegetables which enable African countries to be inserted in global value chains (Granleese, 2009, Daviron and Ponte, 2005; Dolan and Humphrey, 2000).As a result, limited evidence exists on how governance plays out on staple food value chains that are usually relegated to domestic and regional markets (Minten, 2015).

Maize is Zambia's staple food crop and maize farming is the most dominant agriculture activity among smallholder farmers in Zambia. Maize alone accounts for about 60 percent of the country's calorie intake and together with other cereals provides almost two-thirds of the dietary energy supply (Goverahet al, 2008; Mason and Myers, 2013; Mwanamwenge and Harris, 2017). Therefore, it is not surprising that grain milling is a dominant sub-sector within Zambia's food-processing sector (Saasa, 2000; Hampwaye and Søren, 2014).Further, it has been established by a number of studies on food processing in Zambia that the majority of local owned firms are engaged in maize processing and these range from very small enterprises (hammer millers) to fairly large enterprises (Saasa, 2000; Sutton and Langmead, 2013; SAFIC 2014). Further, the bulk of these maize processing firms are concentrated along the line of rail mostly Lusaka, Central and Copperbelt provinces. This is partly because the demand for processed maize is highest in urban areas.

While a number of studies have been done that link governance to agri-food value chains in Africa (Dolan and Humphrey, 2000; Fold, 2002, Ponte and Ewert, 2009; Minten et al, 2017), there is limited evidence on domestic food value chains especially as it relates to staple foods. Further, majority of studies conducted on Zambia's staple food value chain (Maize) have tended to focus on small-scale producers leaving the perspective of the local processing firms unexplored. The processing firms are at the node that adds more value in the maize chain and remain key in building industrial capabilities in Zambia. This paper therefore seeks to address this gap in empirical research by attempting to understand the organisation and forms of chain governance in Zambia's maize value and its 
implication on local maize processing firms. It is important for the value chain to operate efficiently and competitively at each node as a way of improving its contribution to the growth of the food processing industry which could ultimately lead to increased employment and income and therefore poverty reduction. One way of ascertaining this is by analysing the power relations and coordination mechanisms of the chain.

The paper aims to address three objectives, first to understand how the Zambian maize value chain is organised, second, to establish the governance modes obtaining at different nodes of the value chain and third to ascertain the implication of chain governance on local processing firms. In value chain literature, chain governance is the relationship of power among firms in a production network (Gereffi et al, 2005, Minten et al, 2015). How this power plays out differs from region to region, sector to sector and from one value chain to another.

The paper contributes to literature in two ways. First the application of a GVC model on a value chain that is more regional than global. A few studies have attempted to apply the GVC framework on value chains with a local or regional geographical scope but these have mostly focussed on the role of standards, value chain upgrading and transformation (Barrientos et al, 2015; Minten et al, 2015; Karki et al, 2016) or how local value chains can benefit or be integrated into global value chains (Feyaerts et al, 2019; Beverelli et al, 2017).Second, by virtue of being a staple food value chain in a developing country where issues of food access and security are at play, what is observed in the Zambian maize value chain is that governance deviates from what we often see in typical GVC scholarship (Dolan and Humphrey, 2009) where there is a strong chain driven often brand retailers. In this case, there is a strong hand of government in chain governance.

The remaining part of the paper proceeds as follows. After giving are view of the literature on governance in value chains and outlining the theoretical framework. The next section considers the methods that were used to collect data. This is followed by an analysis of the empirical data based on the study's research questions. The presentation of findings begins with an overview of the maize value chain and its organisation, after which the different forms of governance at each node are identified. Finally, several implications for local processing firms derived from value chain governance are considered and the paper argues that government interference in the chain results in shifting power relations within the chain. The unfettered manner in which government intervenes negatively affects the private actors including the maize millers who are at the centre of value addition in the value chain.

\section{LITERATURE REVIEW}

\subsection{Global Value Chain}

Governance, within global value chain literature has been defined as a non-market coordination of economic activity. It occurs when some actors within the chain work set standards while the other actors work according to the parameters set by others (Dolan and Humphrey, 2000; Humphrey and Schmitz, 2002; Gereffi et al, 2005; Ponte and Sturgeon, 2014).

Various scholars have come up with a nomenclature for the different forms that governance takes in GVCs. Some have categorized the different forms of governance based on the type of chain actors that act as lead firms. In this case, Gereffi $(1994 ; 2001)$ distinguishes between producer driven and buyer driven value chains. Producer-driven chains are characterized as capital and high technology industries such as the automotive industry and the lead firms or chain drivers are usually those that control the production systems. Producer-driven chains are set in such a way that the not so highly rewarding activities are out-sourced upstream to a network of suppliers who are bound by contracts to produce according to the given specifications (Gereffi et, al, 2005). On the other hand, buyer -driven chains are mostly found in labour-intensive industries such as the clothing industry and the toys' industry. Here, parameters are set by large retailers and brand names whose focus are on the design and marketing and do not necessarily possess any production facilities (Gereffi, 1994).Agro-food value chains are also located in the buyer- driven category. Evidence has shown that supermarket chains in developed countries set requirements for producers and suppliers in developing countries (Dolan and Humphrey, 2000; Humphrey and Schmitz, 2004). Further, within developing countries, there has been a general rise of regional supermarket chains with similar requirements on local agrofood producers (Reardon et al, 2007). The horticulture value chain between some African countries 
and European countries provide an example of a buyer driven chain in which retailers in Europe play a decisive role in specifying what is to be produced, under what conditions it is to be produced and so on (Dolan and Humphrey, 2000). However, other GVC studies have focussed more on understanding how coordination takes place at each node of the value chain (Humphrey and Schmitz, 2004; Gereffi and Luo 2014) and on the normative elements framing buyer-supplier relations (Gibbon and Ponte, 2005; Gibbon et al, 2008).

Gereffi (2014) acknowledges that the dichotomous categories of buyer driven and producer driven value chains are too narrow to capture the complex nature of governance structures in value chains. $\mathrm{He}$ argues that this limitation has been addressed by developing the five typologies of GVC governance structure and identifies five (5) possible forms of value chain governance. These include, markets, modular, relational, captive and hierarchy (Humphrey and Schmitz, 2002; Gereffi et al, 2005:82-88; Gereffi, 2014; Ponte et al, 2014). The conditions under which these forms of governance apply are dependent on three factors. First the complexity of the information and knowledge transfer required to sustain each transaction (product and process specification), second, the extent to which information and knowledge can be codified and therefore transmitted efficiently without transaction specific investments between the parties to the transaction, and third, the capabilities of actual potential suppliers in relation to the requirements of the transaction.

While this categorisation provides a practical way of differentiating between different forms of governance, it has been critiqued for being too narrow and firm-centric (Bair, 2005). Other scholars have investigated the co-existence of multiple forms of governance, emphasising between coordination, control and power within GVCs (Gibbon and Ponte, 2005).

The implications for governance have further been explored by Ponte and Sturgeon (2014) through the concept of multipolarity. They analyse the power of different actors both firm and institutional that can influence diverse outcomes. A multi-polar approach to governance captures the wide range of external actors that can influence standards, including public authorities, consumer expectations and civil society pressure. Different GVC and GPN analysts have examined governance in relation to the power of lead firms over suppliers and asymmetric bargaining positions between them (Henderson et al, 2002; Bair, 2008). Ponte and Sturgeon (2014), builds further on the governance debate by stating that governance can occur at different levels within the value chain, away from the unipolar characterization in much of literature. In addition to unipolar, it can be bipolar or multipolar governance existing within a particular value chain.

Ponte (2014) extends the discussion on governance further by introducing the analytical lens of 'polarity'. He argues that chain governance occurs along a continuum of unipolarity to multipolarity. Therefore, chain governance can take the form of unipolar in which one group of lead firms occupying specific functions in a chain have the dominant role in governing the chain. This has been the focus of most GVC literature on governance be it producer or buyer driven chains. On the other hand, we have bipolar or twin-driven chains where two actors with different functional positions both drive the chain although in different ways (Islam, 2009; Ponte, 2014). Governance in multipolar driven chains is shaped by the actions of powerful actors both within and outside the chain. Chain dynamics and governance in these types of chains is more complex than is the case in unipolar chains. However, most studies that have this inclination see governance, especially the 'multipolarity' type to be restricted to standards and regulations set by state agencies or international non-governmental organisations, labour unions that have an influence on GVC governance (Tran et al, 2013; Ponte, 2014).Further, much of this analysis has been informed by North-South relations between a dominant group of buyers and fragmented suppliers largely from developing countries

Along the debates regarding chain governance and what it entails, GVC scholars seem to all agree that there is an eminent component of 'chain drivers' or lead firms that drive the chain (Gibbon, 2001; Gibbon and Ponte, 2005; Gibbon, 2008; Ponte and Sturgeon, 2014). All these point to the extent to which chain governance improves or limits the capacity of individual actors to improve their welfare within the chain hierarchy.

\section{ANALYTiCAl FrameWORK}

This study draws from the global value chain literature on governance which identifies five (5) possible forms of value chain governance namely, markets, modular, relational, captive and hierarchy 
(Gereffi et al, 2005:82-88). In this case it entails that the market governance arises when transactions are easily codified, product specifications are relatively simple and the suppliers have the capability to produce the product in question with little input from the buyers. Practically this entails that these are arms-length transactions involving a number of buyers and sellers with limited information shared between parties and while repeat transactions are possible, they are not always guaranteed (Webber and Labste, 2010; Ouma et al, 2017). Modular value chain governance arises when the ability to codify specifications extends to complex products. This comes about when product design is modular meaning the 'physical building blocks' of a product are loosely coupled and designed to be relatively independent of one another because of standardized interfaces and visible design rules, which permit some components and sub-systems to be disaggregated and recombined into a large number of product variation (Gereffi et al, 2005; Ponte et al, 2014). In short, there is high complexity of transactions, high ability to codify transaction and high capabilities in the supply base. Relational value chain governance may arise where there is a high complexity of transaction but low ability to codify transaction yet having a high capability in the supply base. Tacit knowledge has to be exchanged between buyers and sellers but lead firms gain motivation from highly competent supplier to the extent that they are able to outsource to gain complementary competencies (Gereffi et al, 2005; Ouma et al, 2017). Captive governance occurs where there is a high complexity of transactions, high ability to codify transactions yet low capabilities in the supply base. This situation calls for great interventions and control on the part of the lead firm resulting in transactional dependence as the lead firms seek to lock-in suppliers to exclude others from reaping the benefits of their efforts (Gereffi et al, 2005; Ponte, 2014). On the other hand, hierarchy governance occurs when products specifications cannot be codified, products are complex and highly competent suppliers cannot be found, then lead firms will be forced to develop and manufacture products in-house. It is important to note that the market and hierarchy types of governance are extremes and rarely the case in reality rather the most common ones are from modular to relational (Gereffi et al, 2005:86). The five typologies of value chain governance structure are able to coexist in one value chain as governance structures may vary at each stage of the chain (Ponte, 2014).

\section{Methodology}

The study utilised both primary and secondary data. Primary data was collected using five (5) different interview guides for chain actors at different nodes of the chain including producers, traders, processors, retailers and key stakeholder organisations in the sector. This tool was considered plausible for collecting in-depth information and understanding the coordination dynamics at different nodes of the value chain. The interviews were carried out during November 2016 to December 2018 in three phases. The first round of data collection involved in-depth interviews with eight local maize processing firms located in Lusaka(6), Copperbelt (1) and Central (1) provinces. This was followed by a second round of data collection with other chain actors and stakeholders identified from the first round of interviews with the maize processing firms and review of secondary data. Primary data from processing firms as well as secondary data from the Ministry of Agriculture reviewed that small and medium scale farmers were the main producers of maize in Zambia. In light of this, twenty (20) small-scale farmers from Southern (5), Lusaka (5), Central (5) and Copperbelt (5) were interviewed including (15) grain traders all based in Lusaka that supply the firms were identified and interviewed. In addition, five (5) supermarkets and five (5) wholesales participating in the chain were interviewed as well as the ten (10) key stakeholders that include business associations, government agencies and research institutes. Finally, the third round of interviews was conducted with all the eight (8) processing firms so as to establish if anything had changed since the first round of interviews and to clarify on salient issues that emerged from the second round of interviews with other chain actors and key stakeholders. This brought the total number of interviews to 71 . In addition to primary data, the findings were enriched by secondary. Secondary data sources included Government reports on crop forecast survey for a ten- year period, food balance sheets for a ten-year period, policy documents, national development plans, economic reports and other expert institutional and individual reports. Several other scholarly books, articles, discussion papers, working papers and research papers were used.

Once collected, data were transcribed and organized in themes and analysed thematically. 


\section{FINDINGS}

This section presents the findings. It begins with the organisation of the Zambian maize value chain from input supply up to retail. This is followed by an analysis of governance structure at each node of the value chain and the implication on the maize processing firms.

\section{ORganisation of The Maize VAlue Chain}

Apart from being consumed in its unprocessed form, maize grain can be processed into a variety of other products and by-products which include maize meal (maize flour), samp (dehulled kernels) and grit used in the making of snacks as well as stock-feed. This paper focused on maize grain to maize meal/flour value chain, which is the country's staple. The maize meal value chain consists of six stages which include: Input supply, production, marketing, processing, retailing and consumption.

\subsection{Suppliers of Input}

It was established earlier that the smallholder farmers accounted for the bulk of the maize grain produced in Zambia. Agro chemical and seed suppliers are spread across the country. The majority of smallholder farmers access farming inputs from these suppliers of input the Farmer Input Support Programme (FISP). FISP is a government programme that is aimed at providing seed, fertiliser and other farming inputs to smallholder farmers at subsidised prices. It is limited to smallholder farmers. The overall idea is to boost production so that the country is food secure and to reduce rural poverty. As such governments FISP expenditure is drawn from the poverty reduction strategy programme under the ministry of Agriculture (Mason and Myers, 2013.; Chapoto and Chisanga, 2016).

\subsection{Production}

At the level of production, maize is produced by farmers who are categorised into two: the smallholder farmers and the large scale commercial farmers. The smallholder farmers account for the bulk of total annual maize production. This has been attributed to government policy and interventions at production level (Mason et al, 2013; Chapoto and Chisanga, 2016). Currently, they account for 80 percent of total maize production while the commercial farmers account for the remaining 20 percent. Maize is planted at the beginning of the faming season which is signalled by the first rains, and this varies from season to season due to variations in rainfall patterns. The start of a season could be between November and December while harvest takes place between April and May. Once harvested, smallholder farmers either store their maize on-farm for consumption or to speculate on high prices by selling later in the season while commercial farmers may store their maize on-farm or sell to processors.

\subsection{Marketing}

It has been established that most smallholder farmers depend on maize sales for incomes (CUTS, 2016), that being the reason, majority of farmers sell their maize soon after harvest. The Smallholder farmers can either sell to the Food Reserve Agency(FRA), grain traders, processors or fellow farmers. The commercial farmers have a number of marketing channels including processors, traders and export. However; commercial farmers are by law not permitted to sell to FRA because the grain marketing mandate for FRA is specific to smallholder farmers.

The smallholder farmers begin marketing their maize as early as June when the moisture content is still high. Consequently, the prices fetched for maize at this point are low. Maize prices are at their lowest between June and July following the harvest period. They then begin to rise gradually and peak between February and March before they begin falling again from April onwards, just before harvest.

"Sometimes we are forced to sell early when the prices are low because we have some pressing financial needs, children need to go to school, we need to buy some groceries for the family, so we sell to these traders even if the price is low while we wait for FRA to start buying from us" (Interview with a Farmer in Southern Province, 11/08/2017).

The key player in maize marketing is the FRA which buys the bulk of the marketed surplus. This is followed by the grain traders who buy grain for resell to the processors or export markets depending on the market that is available at that time. Further, the traders also supply one another and these transactions are usually between small scale traders and large scale traders. This is one way that the large scale traders cut down on transaction costs of dealing with smallholder farmers and going into 
remote areas to source the maize grain. The FRA on the other hand stores the maize they buy as strategic reserves which can later be sold to millers when there is a deficit to prevent mealie meal prices from skyrocketing. They also sell their carry over stock to export markets.

\subsection{Processing}

Maize processors include millers, breweries and animal feed manufacturers. Within the milling category, there are small-scale millers and large scale millers. A few of the Zambian owned maize milling firms are large scale. The industry is dominated by large foreign owned firms like National Milling which commands a 22 percent market share followed by antelope milling with a 20 percent market share (Chauvin et al, 2017). The remaining 58\% is what the rest of the processing firms, majority of whom are local firms, have to share. The study considered the maize millers value chain and found that there are three channels through which the millers acquire maize grain input: either directly from farmers, through grain traders or FRA. However, millers indicated that they preferred to buy maize from FRA for a number of reasons. First because it was easier to handle logistically than buying directly from individual farmers. Secondly, FRA maize was cheaper though it came with conditions.

"it is easier to handle logistically as we buy in big quantities compared to buying from individual farmers" (Firm C, personal communication.15/11/2016).

In addition, millers argued that buying from grain traders is risky in that if it is in deficit season and FRA offloads their stocks to millers, it implies that mealie meal prices automatically go down and those who sourced their inputs from the private traders would be at a loss.

\subsection{Retail}

Once maize meal has been processed, it follows a formal or an informal channel to get to the end users. Formally it is distributed to wholesale and retail stores. The maize meal is accessed at wholesale prices and is sold at retail prices to consumers or at semi-wholesale prices for maize meal traders. The maize meal traders later resell to final consumers in high density areas or those who reside in far flung areas away from the central points where the wholesale and retail stores are located. At least 3 processing firms(Firms D, S and $\mathrm{M}$ ) interviewed mentioned that they had embarked on a marketing program to cater for consumers in high density areas who may shun buying from supermarket chains by introducing mobile van sales. The major formal retailers are supermarket chains such as Pick n Pay, Spar, Shoprite, Game stores, Melisa, Cheers and other grocery stores.

\section{GOVERNANCE STRUCTURES IN THE ZAMBIAN MAIZE VALUE CHAIN}

Interviews with the processors and key stakeholders revealed that maize is a political commodity in Zambia. This is corroborated by the findings of the Indaba Agriculture Policy and Research Institute (IAPRI) on the politics of maize (Mason et al, 2013; Chapoto et al, 2015). Government has been intervening extensively in the sector through government agencies, ministerial and presidential pronouncements. The interventions are purported to ensure national food security which in the Zambian context entails beingmaize self-sufficient. The five typologies of governance as espoused by Gereffi et al (2005)were applied at each node of the maize value chain in order to understand the coordination structure that exists.

At the node of input supply, between smallholder farmers and suppliers of inputs, it was observed that the transactions take the form of market, were farmers go to purchase their inputs at the agro suppliers stores. However, these transactions in the case of smallholder farmers are facilitated by the government through FISP. The farmers are provided with e-vouchers which can be used to redeem inputs from agro dealers. There is a specified timeframe for this activity and this is usually at the beginning of a planting season. Additionally, it is also dependent on when government is able to release funds for this purpose.

Once maize is produced, the smallholder farmers have three main channels through which they can market their produce. These include, grain traders, who enter the market early prior to the start of a marketing season, processors and FRA. The FRA enters the market at the start of the marketing season. The FRA announces the start and end of the marketing season which is usually between June and October annually. It is important to note that the FRA's announcement is critical for the private actors in the value chain. This is because FRA is the largest buyer of maize in the country. By virtue 
of being the largest buyer, its announcement of its buying period and the price, is taken as the official maize buying/marketing season and the FRA price is taken to be the 'maize floor price' or an indicative price for other actors in the market. The FRA price is usually above the normal market price of maize and varies from season to season and in some cases government officials overrule the agency and dictate a different price which is higher. For instance in 2015, FRA announced a price of K70 (ZMW) per 50 Kilogram bag of maize but the Republican President later instructed the FRA to increase the price to K75 (ZMW)(CUTS, 2016). The FRA announcement also includes information on the quantity that the agency intends to purchase based on that year's crop forecast survey. The quantity is typically pegged at 500,000 metric tonnes although FRA has been exceeding this quantity in previous years. Therefore, a delay in this announcement raises a lot of anxiety among private actors.

The grain traders revealed that their strategy is to enter the market before FRA announces the marketing season and their buying price. At that time of the year, the farmers would have just harvested their crop and are desperate for income so the traders are able to bargain for a good price. The transactions take the form of spot market transactions and traders buy at the farm-gate. Grain traders take care of their own transport costs to their point of storage and final sale. The transactions can be a one -off or repeat transactions but there is no contract of sale whatsoever. This depicts a market type of coordination where market price is the main coordinating mechanism.

Once FRA enters the market, there is reduced participation of the grain traders as they have to share the market. In the remotest parts of the country, FRA is the only channel through which farmers have market as such most farmers sell all their surplus maize grain to FRA, making FRA the largest maize buyer in the country. FRA appoints agents at assembly points where the farmers can deliver their maize who are trained in standards and buying mechanisms of the FRA. These agents sensitise the farmers on the quality of grain that FRA demands. The maize has to be Grade A according to the Zambian standards, ZAB 186 in maize grain. For example, it should have less than 2 percent of broken grain, shrivelled grain, foreign matter, brown grain among other parameters. The farmers also get further training and support on harvest and storage through the ministry of agriculture's crop extension services. FRA carries out training for its buyers to communicate to the farmers yearly. Once a farmer has successfully sold to FRA, they have to await payment which can be collected from selected banks. This can take months in some marketing seasons depending on how quick government is able to release payment. Therefore, some farmers with immediate need for cash may opt to sell to grain traders or processors even at a lower price than what FRA is offering. The coordination mechanisms at this node depict a captive configuration in which strict adherence to quality has to be enforced by FRA considering its objective to acquire maize grain as strategic reserve. This may not be the case with traders who plan on reselling the grain immediately. As such FRA invests a lot of resources on training staff and agents who later advise farmers on the quality of maize that is expected. The farmers are also dependent on FRA for the price which may be slightly higher than what the private players may offer.

At the processing node, the millers access their inputs either directly from the farmers, through grain traders or from FRA. Transactions between processors and trader generally take the form of spot market. The traders deliver their stock to millers who buy at the agreed price. The payments are done immediately or within a few working days. All the millers interviewed reviewed that they did not have permanent supply agreements with the grain traders because it all depended on the price that was offered.

"There is no relationship whatsoever, it is just business, we cannot have a binding agreement because the supplier might find someone offering a good price or we might find a cheaper supplier" (Personal communication with Firm D, 22/11/2016).

In this case it can be said that price is the main coordination mechanisms but other standard requirements such as quality grade of the grain, moisture content, and amount of foreign matter were also considered.

"we grade it[maize] through our system and we if it is found that the moisture content is high, it has a lot of foreign matter and it doesn't look like grade A....we return a truck of this sort because it compromises our quality" (Personal communication with Firm S, 21/11/2016). 
When millers source their inputs from FRA, the FRA drafts a contract which specifies the price at which the processed maize meal can be sold and the markets were it is to be sold. In spite of this, the maize grain is sold to millers at subsidised prices. Below the price that FRA purchased the maize grain from farmers.

"With FRA, there is always a contract which comes with terms and conditions. The challenge here is with the terms and conditions because FRA maize always has conditions. Some of the conditions like we had from the last contract, I think the contract ended in August 2016. We had to sell our product at a certain price, fixed and then we were not allowed to export any of the products and by-products from their maize, be it maize meal or maize bran. And then the quantity also, you will be allocated a specific quantity per month" (Personal communication with Firm A, 02/11/2016).

The processors found the specifications on quantity allocation to be a hindrance to their productivity because in some cases it was way below their production capacity. ".. the allocation of a specific quantity is very restrictive.... so you find that whatever quantity we get, we finish it in 2 weeks, so the other 2 weeks you have to wait for the next month for the next allocation. So that's the biggest challenge" (Personal communication, with Firm A, 02/11/2016 and Firm S, 21/11/2016). The coordination here is characteristic of a captive coordination as the FRA dictates the prices of the maize meal having provided the inputs and have to constantly monitor that the maize meal prices have indeed gone down and that no exports of maize meal are made during that period.

At the node of marketing the maize meal, the millers have two (2) markets available, the domestic market and the export markets. Locally the processors can sell to supermarket chain stores, convenience stores, wholesale and breweries. The study looked at the millers to supermarket chain stores relationship. It was found that processors supplying the supermarkets entered into contracts with the stores. The contracts state the quantity to be supplied, the delivery schedule as well as the price at which the products will be supplied. Individual processors take care of the delivery logistics in terms of transport to the store and putting the product on the shelves. This relationship is therefore referred to as modular, that is, there is high information and complexity yet ease of codification and high supplier capabilities. The coordination structures are summarised in Table 1.

Table1. Governance structure at each node

\begin{tabular}{|c|c|c|}
\hline Value chain node & Characteristics & Governance mode \\
\hline Production & $\begin{array}{l}\text { Agro-dealers to farmers } \\
\text { (Government support to farmers through FISP ) }\end{array}$ & Market \\
\hline Marketing & $\begin{array}{l}\text { Farmer to Processor } \\
\text { Farmer to Grain trader } \\
\text { Farmer to FRA }\end{array}$ & $\begin{array}{l}\text { - Market } \\
\text { - Market } \\
\text { - Captive }\end{array}$ \\
\hline Processing & $\begin{array}{l}\text { Grain trader to Processor } \\
\text { FRA to Processor }\end{array}$ & $\begin{array}{l}\text { - Market } \\
\text { - Modular }\end{array}$ \\
\hline Retail & Processor to Retailer & - Modular \\
\hline
\end{tabular}

\section{DISCUSSION AND IMPLICATION}

Drawing on the theoretical framework adopted for this study, the driver or lead of the maize value chain cannot be identified with one actor. This is consistent with Ponte et al (2014) who argued that a single chain can have different drivers at each node. However, what is profound with the Zambian maize value chain is that power balances shift due to interference from government agencies and high government officials. This interference was labelled as 'unpredictable' by chain actors and non-state stakeholders. The governance structures change with seasons and from year to year. For instance, upstream, the FRA controls the prices of maize because of being the largest buyer. Resulting from this, the FRA's announced price inevitably becomes the maize 'floor price' and this price is not known until it is announced which adds to the uncertainty on the part of private actors. This has an effect on the processors' operations as a high price entails that their input costs raise and passing on this effect to consumers may require some lobbying to the government if the proposed increase goes beyond what is deemed 'acceptable' (Mason et al, 2013b).

Duringmaize bumper harvest, the FRA will only purchase maize stocks for reserve and may notoffload its stocks on the domestic market but would opt for export markets. In this case, the maize processors will have to source their maize inputs either from grain traders or directly from farmers at 
agreed prices. However, during the same year if the bulk of maize grain is exported by traders and the domestic stocks begin to dwindle, the price of maize goes up and inevitably the millers increase their prices. Such a scenario may force the FRA to intervene by offloading cheap maize stocks to processors on the domestic market. FRA's intervention is aimed at ensuring that maize meal prices decline to levels that the ordinary urban consumer can afford. This entails selling maize grain at subsidized prices with conditions dictating the price and markets for millers. In this case, the price agreed upon and the market is limited to domestic and not exports markets. This intervention may affect the processors who may have stocked up on maize as privately purchased stocks become more expensive and a loss for such millers it also becomes a challenge for firms whose main customers are in export market. The millers then ensure that their buyers reduce prices accordingly when they begin to supply them with maize meal of FRA origin.

Downstream, millers who supply the supermarkets have to adhere to the requirements set by these retailers. The millers are responsible for transporting their finished product to supermarkets as well as stacking the products on the shelves. In other ways, the millers bear all the logistic costs as demanded by the retailers, representing modular governance. However, what is clear is that the role of government through the FRA is not limited to selling maize grain to the millers but goes beyond processors to ensure that consumers get the staple food at reasonable prices. Arising from the conditions set by FRA, the retailers are also forced to enforce these conditions by limiting stock sold to individual customers.

Based on the findings, it can be argued that there are shifting power relations or governance modes in the Zambian maize value chain. This change in governance patterns depends on the maize input stocks available at a particular time. When there is a deficit, firms anticipate the participation of the government through FRA in the maize markets. However, even in times of surplus, there is always uncertainty among private players who term government's intervention in the sector as 'unpredictable'. Consequently, the actions of the private players (grain traders and millers) are based on speculating the government's next move. This arbitrary intervention and the uncertainty it creates are retrogressive to the operations of the private actors and overall value chain competitiveness.

\section{CONCLusions}

The study has used the GVC framework to understand governance in the Zambian maize value chain. Maize processing is an important subsector within the food processing industry in Zambia as the majority of food processing firms are engaged in grain processing, especially maize processing. Overall, the food processing industry in Zambia has enormous potential for diversifying the economy away from its huge dependence on mining and to contribute to employment, increased incomes and consequently poverty. This justifies the need for food markets that operate efficiently in order to benefit the private actors, especially the food processing firms which are at the centre of value addition in the value chain. The way in which Zambia's maize value chain is organised from input supply all the way to consumption and export shows different actors with different levels of engagement and therefore different forms of coordination at each node. This is consistent with the findings of other scholars who argue that different forms of coordination can exist in one value chain (Ponte et al, 2014). However, away from the buyer and producer driven dichotomy as alluded to by Gereffi (1999), the analysis shows that the Zambian maize value chain is highly externally driven by the government. Overall, the participation of FRA at the level of marketing and processing engenders uncertainties among private chain actors because they have to keep speculating FRA's next move. When wrongly speculated, some private actors, millers inclusive have had to incur losses. This has implication on the prospects for competitiveness for the value chain as a whole. From this characterisation, it can be said that the overall chain coordination is to a large extent driven by the government through FRA and high government officials. From the GVC analytical framework, the study finds that the Zambian maize value chain can neither be categorised as buyer driver nor producer driven but that the different nodes of the chain have different coordinating mechanisms.

\section{REFERENCES}

Bair, J. (2005) Global Capitalism and Commodity Chains: Looking Back, Going Forward'. Competition and Change, 9 (2), 153-180.

Bair, J. (2008) Analyzing Global Economic Organization: Embedded Networks and Global Chains Compared. Economy and Society, 37 (3), 339-364. 
Barrientos, S., Knorringa, P., Evers, B., Visser, M., and Opondo, M. (2015) Shifting regional dynamics of global value chains: Implications for economic upgrading and social upgrading in African horticulture. Environment and planning A.O (0) 1-18

Chapoto, A. and Chisanga, B. (2016) Zambia: Agriculture Status Report. Indaba Agriculture Policy Research Institute (IAPRI). Lusaka

Chapoto, A.; Zulu-Mbata, O.; Hoffman, B.; Kabaghe, C.; Sitko, N.; Kuteya, A. and Zulu, B.; (2015). The Politics of Maize in Zambia: Who holds the Keys to Change the Status Quo? Working Paper 99, IAPRI, Lusaka.

Dolan, C. and Humphrey, J. (2000) Governance and Trade in Fresh Vegetables: The Impact of UK Supermarkets on the African Horticultural Industry. Journal of Development Studies37 (2): 147-76

Fold, N. (2002). Lead Firms and Competition in 'Bi-polar' Commodity Chains: Grinders and Branders in the Global Cocoa-chocolate Industry. Journal of Agrarian Change. Vol. 2 (2), 228-247

Gereffi, G. (1994). 'The organization of buyer-driven global commodity chains: how US retailers shape overseas production networks' Chapter 5 In: Gereffi, G. and Korzeniewicz (eds.) Commodity Chains and Global Capitalism. Westport, CT, Praeger.

Gereffi, G. (2001). Shifting governance structures in global commodity chains, with special reference to the internet. American behavioral Science. 44:1616-1637

Gereffi, G., Humphrey, J., Kaplinsky, R. and Sturgeon, T. (2001) Globalisation, Value Chains and Development. IDS Bulletin, 32 (3), 1-8

Gereffi, G., Humphrey, J. and Sturgeon, T. (2005) The governance of global value chains. Review of International Political Economy, 12 (1), 78-104.

Gereffi, G. and Luo, X. (2014) Risks and Opportunities of Participation in Global Value Chains. Journal of Banking and Financial Economics 2(4)2015, 51-63

Gibbon, P. (2001) Upgrading Primary Production: A Global Commodity Chain Approach. World Development, 29 ( 2), 345-363,

Gibbon, P and Ponte, S. (2005) Trading Down: Africa, Value Chains, and the Global Economy. Temple University Press, Philadelphia.

Gibbon, P. Bair, J. and Ponte, S. (2008). Governing global value chains: an introduction. Economy and Society, 37 (3), 315-338.

Govereh, J.; Jayne, T.S.; and Chapoto, A. (2008). Assessment of Alternative Maize Trade And Market Policy Interventions in Zambia. Working Paper No. 33. Lusaka, Zambia: Food Security Research Project.

Hampwaye, G. and Jeppesen, S. (2014). The role of state- business relations in the performance of Zambia's food processing sub-sector. In: Rogerson, C.M. and Szymańska, D. editors, Bulletin of Geography. Socioeconomic Series, No. 26, Toruń: Nicolaus Copernicus University, pp. 83-92.

Humphrey, J. and Schmitz, H. (2004). How does insertion in global value chains affect upgrading in industrial clusters? Regional Studies, 36 (9), 1017-1027.

Henderson, J.; Dicken, P.; Hess, M.; Coe, N. and Yeung H.W.C (2002) Global Production Networks and the Analysis of Economic Development, Review of International Political Economy, 9:3, 436-463

Islam, M.S. (2008). From pond to plate: Towards a twin-driven commodity chain in Bangladesh shrimp aquaculture. Food Policy. Vol. 33. 209-223

Karki, S.E., Fasse, A. and Grote, U. (2016) The role of standards in domestic food value chains in Sub-Saharan Africa: A review article. African Journal of Horticulture Science. 9:41- 53

Mason, N.M and Myers, R.J. (2013) Effects of the Food Reserve Agency on Maize Market Prices in Zambia. Agricultural Economics. 44 (2013) 203-216.

Mason, N.M.; Jayne, T. S. and Mofya-Mukuka, R. (2013a). A Review of Zambia's Agricultural Input Subsidy Programs: Targeting, Impacts, and the Way Forward. Working Paper 77. Indaba Agriculture Policy Research Institute (IAPRI). Lusaka.

McCormick, D. and Schmitz, H. (2001) Manual For Value Chain Research On Homeworkers In The Garment Industry. Institute of Development Studies, University of Sussex.

Minten, B.; Tamru, S.; Engida, E. \& Kuma, T. (2016)Transforming Staple Food Value Chains in Africa: The Case of Teff in Ethiopia. Journal of Development Studies, 52:5, 627-645

Minten B., Dereje, M., Engida, E. \& Kuma, T. (2017) Coffee value chains on the move: Evidence in Ethiopia. Food Policy, 1-14.

Mwanamwenge, M. and Harris, J. (2017) Agriculture, Food systems, diets and nutrition in Zambia. Policy Brief. Lusaka, Zambia: Hivos and IIED: Sustainable Diets for All Project 
Neilson, J. and Pritchard, B. (2009) Value Chain Struggles. Institutions and Governance in the Plantation Districts of South India. West Sussex: Wiley-Blackwell.

Ouma, E.; Ochieng, J.; Dione, M. and Pezo, D. (2017) Governance structures in smallholder pig value chains in Uganda: constraints and opportunities for upgrading. International Food and Agribusiness Management Review. Vol. 20(3). 307-319.

Ponte, S. (2014) The Evolutionary Dynamics of Biofuel Value Chains: From Unipolar and Government-Driven to Multipolar Governance. Environment and Planning A, 46: 2, 353-372

Ponte, S. and Ewert, J. (2009) Which Way is "Up" in Upgrading? Trajectories of Change in the Value Chain for South African Wine. World Development.Vol. 37 (10) 1637-1650.

Ponte, S and Gibbon, P. (2006) Quality standards, conventions and the governance of global value chains. Economy and Society, 34(1),1-31.

Ponte, S.; Kelling, I.; Jespersen, K.S.; and Kruijssen, F. (2014) The Blue Revolution in Asia: Upgrading and Governance in Aquaculture Value Chains. World Development.64, 52-64.

Ponte, S. and Sturgeon, T. (2014)Explaining governance in global value chains: A modular theory building effort. Review of International Political Economy, 21:1, 195-223

Reardon, T.,Henson S., and Berdegue, J. (2007)Proactive fast-tracking' diffusion of supermarkets in developing countries: implications for market institutions and trade. Journal of Economic Geography 7 (2007) pp. $399-431$

Saasa Oliver (2000) Small scale Food processing in Zambia, CTA Working Document Number 8015

SAFIC Zambia (2014) Agriculture development in Zambia: The role of food processing Industry.Briefing Paper.

Sutton, J. and Langmead, G. (2013). An Enterprise Map of Zambia. London: International Growth Centre.

Tran, N.; Bailey, C.; Wilson, N.; and Phillips M. (2013) Governance of Global Value Chains in Response to Food Safety and Certification Standards: The Case of Shrimp from Vietnam. World Development. Vol. 45. 325-336,

Webber, C.M. and Labaste, P. (2010) Building competitiveness in Africa's agriculture: a guide tovalue chain concepts and applications. Agriculture and Rural Development. The World Bank, Washington, WA, USA.

Zambia Development Agency (ZDA) (2013) Manufacturing Sector Profile. ZDA, Lusaka.

Zambia Development Agency (ZDA) (2014) Food processing Sector Profile. Ministry of Commerce and Industry: Lusaka

Zambia Development Agency (2014). Agro processing Sector Profile. ZDA, Lusaka

\section{AUTHOR's BIOGRAPHY}

Matildah Kaliba, is a Lecturer and Researcher at the University of Zambia, Department of Development Studies. This article draws data from the author's PhD work under the Successful African Firms and Institutional Change (SAFIC) project which was generously funded by DANIDA.

Citation: Matildah Kaliba. "Food Processing Value Chains in Zambia: Governance in the Maize Value Chain" International Journal of Humanities Social Sciences and Education (IJHSSE), vol 8, no. 2, 2021, pp. 59-69. doi: https://doi.org/10.20431/2349-0381.0802007.

Copyright: (C) 2021 Authors. This is an open-access article distributed under the terms of the Creative Commons Attribution License, which permits unrestricted use, distribution, and reproduction in any medium, provided the original author and source are credited. 